\title{
The Evolution of Anti-Jewish Imagery in Medieval Christian Europe
}

The horrific results of modern antisemitism during the Holocaust have given rise to extensive efforts to trace the history of this modern anti-Jewish thinking. These efforts have inevitably included considerable focus on the impact of traditional Christian imagery of Judaism and Jews on modern antisemitism, despite the conviction in many quarters that modern antisemitism was either non-Christian or perhaps even anti-Christian. The role of Christianity in the evolution of modern antisemitism has been analyzed extensively by many observers, pre-eminently by Jules Isaac. ${ }^{1}$

Of late, a number of researchers in medieval Jewish history have proposed that medieval Christian Europe introduced a new turn in Christian anti-Jewish sentiment. These scholars have suggested that traditional anti-Jewish motifs were bent in increasingly radical directions under the special circumstances of medieval Christian Europe. ${ }^{2}$ Thus, while traditional Christian anti-Judaism played a role in the evolution of modern antisemitism, it was the innovative and radical anti-Jewish imagery produced in medieval Christian Europe that most immediately and most tellingly laid the foundations for the extreme antiJewish stereotypes purveyed by modern antisemites. This innovative medieval anti-Jewish imagery very much fostered the creation of the radical anti-Jewish stereotypes of the antisemitic thinkers and movements; perhaps even more importantly, this legacy from the European Middle Ages predisposed the European population at large to embrace the extreme anti-Jewish stereotypes disseminated by the antisemites. We shall examine briefly this new sense of the role of medieval Christian Europe in providing much of the foundation of modern antisemitism, beginning with pre-medieval Christian thinking and then proceeding to the medieval innovations.

1 The broad conclusions reached by Jules Isaac are nicely summed up in his The Teaching of Contempt, trans. H. Weaver (New York: Holt, Rinehart \& Winston, 1964).

2 These researchers include: G. I. Langmuir, History, Religion, and Antisemitism (Berkeley: University of California Press, 1990) and Toward a Definition of Antisemitism (Berkeley: University of California Press, 1990); A. Sapir Abulafia, Christians and Jews in the Twelfth-Century Renaissance (London: Routledge, 1995); and R. Chazan, Medieval Stereotypes and Modern Antisemitism (Berkeley: University of California Press, 1997) and From Anti-Judaism to Anti-Semitism (New York: Cambridge University Press, 2016).

Ә OpenAccess. () 2021 Robert Chazan, published by De Gruyter. (cc))BY-NC-ND This work is licensed under the Creative Commons Attribution-NonCommercial-NoDerivatives 4.0 International License. 
Jesus and his immediate followers were clearly members of the fractious Jewish community in first-century Palestine. Where precisely they stood during this tumultuous period is unclear. Politically, were they for rebellion against Rome or against it? Where did they stand on the religious and spiritual issues that divided first-century Palestinian Jews? These questions cannot be answered in the absence of sources from the group itself. The only secure knowledge is that they surely perceived themselves and were perceived by others as Jews, attempting to live according to the covenant between God and Israel. In their own eyes, they certainly constituted the Jewish group that understood correctly that covenant; in the eyes of others, they were one of a number of Jewish groups that misread that covenant. ${ }^{3}$

Paul very much complicated the nature of the Jesus movement and its relationship to Judaism and Jews. ${ }^{4}$ Paul, a diaspora Jew who came to Jerusalem seemingly to study and became an active opponent of the Jesus movement, eventually embraced that movement and became a leader with a unique vision of Jesus and his mission. According to Paul, the advent of Jesus set in motion a new and more universal stage in the relationship between God and humanity. In the prior stage, Israel was God's messenger to the rest of humanity; in this new stage, there was an opportunity for all of humanity to enter directly into the divine-human covenant through belief in Jesus. In Paul's view, Jesus had appointed him to the special role of apostle to the gentiles, in order to apprise them of their new and direct access to the divine-human covenant. While Jesus' original followers disagreed with this view of his mission, Paul's perspective won out and shaped the subsequent church.

3 There is a vast literature on the earliest stages of the Jesus movement, and much of it seeks to identify the stances taken by Jesus toward the rest of Palestinian Jewry. Of this vast literature, I have found the following most helpful: G. Vermes, Jesus the Jew: A Historian's Reading of the Gospels (Philadelphia: Fortress, 1981); P. Fredriksen, From Jesus to Christ: The Origins of the New Testament Images of Jesus (New Haven: Yale University Press, 1988); J. D. Crossan, The Historical Jesus: The Life of a Mediterranean Jewish Peasant (New York: HarperCollins, 1991); and E. P. Sanders, The Historical Figure of Jesus (London: Penguin, 1993).

4 There is likewise a vast literature on Paul, again with considerable focus on Paul's views of Judaism and Jews. The literature on Paul benefits from a body of sources from Paul himself. Helpful recent perspectives on Paul can be found in: J. G. Gager, Reinventing Paul (Oxford: Oxford University Press, 2000); F. Watson, Paul, Judaism, and the Gentiles: A Sociological Approach (Grand Rapids: Eerdmans, 2007); and J. D. G. Dunn, The New Perspective on Paul (Grand Rapids: Eerdmans, 2008). Daniel Boyarin's A Radical Jew: Paul and the Politics of Identity (Berkeley: University of California Press, 1994) is useful for Boyarin's mastery of the Jewish sources that influenced Paul. 
The Pauline perspective refashioned the earlier Jesus movement convictions as to who constituted the correct interpreters of the divine revelation to Israel. In the earlier stage of the movement, one group of Jews-Jesus and his followersconstituted the True Israel; those Jews who rejected Jesus were not the True Israel. The Pauline innovation complicated this straightforward dichotomy. Jews who rejected Jesus remained errant; however, both Jews and gentiles who accepted Jesus were now the True Israel. To be sure, Jews who rejected Jesus were still Israel but only in physical terms. Gentiles who accepted Jesus were not biologically Israel, but more importantly they were spiritual Israel. Thus, what eventually became a largely gentile church was projected as the True Israel, while Jews who continued to reject Jesus and his message were Israel in physical terms only.

This complicated perspective translated into a complex view of Judaism and Jews. On the one hand, the early history of the Jews was projected in very positive terms. God had chosen the Jews for the exalted mission of bringing knowledge of him to humanity. Divine revelation was vouchsafed to this group. On the other hand, many in this group subsequently misread the revelation granted to them and failed to recognize the new stage in human history introduced by Jesus. Indeed, these Jews did more than simply fail to recognize his significance-they actively persecuted him. Thus, a once-noble people reached the depths of error and sin. This error and this sin were punished by God through Roman suppression of the rebellion of 66 C.E., destruction of Jerusalem and its temple, and exile of the Jews from the land promised to them (in fact, exile at the hands of the Romans was a theological construct-it did not take place). ${ }^{5}$ Ultimately, Jews would grasp the truth and return to become part of the New and True Israel. What results is classic Christian anti-Judaism, which is a complex combination of veneration for early Israel, denigration of postJesus Jewry, and certainty of an eventual reconciliation.

During the first few centuries of the Common Era, Christian attitudes toward Jews and Judaism did not impact Jewish life significantly. The church was expanding rapidly, thanks largely to the Pauline innovation. This rapid growth fueled concern on the part of the Roman authorities, who recurrently initiated persecutions of the movement. Given these persecutions, the young church was hardly in a position to focus attention and energy on the Jews. Moreover, demographically the centers of church expansion and the centers of Jewish life did

5 On the realities of suppression of the rebellion of $66-70$ C.E. and the lack of an expulsion by the Romans, see R. Chazan, Refugees or Migrants: Pre-Modern Jewish Population Movement (New Haven: Yale University Press, 2018), chaps. 4 and 6. 
not coincide. Church expansion was concentrated in the western sectors of the Roman Empire, while the centers of Jewish population were in Palestine and Mesopotamia. ${ }^{6}$

This lack of impact changed dramatically with Constantine, the Roman emperor who ended the policy of persecution of the church and subsequently made Christianity the state religion. ${ }^{7}$ At this point, the views of the church began to impinge in a significant way on Jewish life. An official church perspective on Judaism and Jews and official church policy vis-à-vis Judaism and Jews were fully articulated by the influential church father Augustine. ${ }^{8}$ Augustine considered himself a disciple of Paul and viewed Judaism and the Jews in Pauline fashion. For Augustine, the early history of the Jews was highly distinguished. God chose them as his human partners and blessed them with divine revelation. At a later point, the Jews failed to grasp the obvious meaning of the revelation bestowed upon them, rejected Jesus, and persecuted him. Like Paul, Augustine envisioned eventual reconciliation between God and his original human partners.

This reconstruction of the Jewish past, present, and future led Augustine to propose a three-part policy vis-à-vis Jews: (1) In recognition of their past distinction, Jews are not to be randomly persecuted in Christian societies; (2) in view of their present error, they are to be limited so that they inflict no religious harm on their Christian hosts; (3) Christians bear the obligation of preaching their truth to Jews regularly and sympathetically, in hopes of bringing closer the future return of the Jews to the true faith of Israel.

The Augustinian policy formed the foundation for generally peaceful Jewish existence in the traditional areas of Jewish settlement under Christian control, which for the Roman Church meant the Mediterranean Basin. With the passage of time, the external circumstances of Jewish life evolved markedly, eventually bringing about new stances on Judaism and Jews. The first major change in Jewish circumstances began early in the seventh century, with the birth of Islam and the rapid conquests of the Muslim armies. Islam exhibited none of the harshness we have discerned in Christian-Jewish relations. According to Muhammed, the

6 The rich Adversus Judaeos literature is sometimes taken as an indication of considerable Christian-Jewish contact during this period. However, this literature seems largely directed at Christian and not Jewish readers.

7 This turning point is emphasized by James Carroll in his popular Constantine's Sword: The Church and the Jews: A History (Boston: Houghton Mifflin, 2001).

8 On Augustine and his stance toward Judaism and Jews, see J. Cohen, Living Letters of the Law: Ideas of the Jew in Medieval Christianity (Berkeley: University of California Press, 1999), chap. 1, and P. Fredriksen, Augustine and the Jews: A Christian Defense of Jews and Judaism (New York: Doubleday, 2008). 
one God in the universe granted two prior revelations-one to Jews and one to Christians. He then decided to grant a third and full revelation to a third and different human community. The first two revelations were genuine, albeit incomplete. The fact that there was a third revelation did not mean failure on the part of the Jews and the Christians-this was simply an inscrutable divine decision. Thus, the key complicating elements in Christian views of Judaism and Jewscontention over one and the same divine legacy and failure on the part of the Jews-are absent in Islamic views of Jews and Christians. ${ }^{9}$

As a result of the remarkable Muslim conquests, the overwhelming majority of Jews in the world during the first half of the Middle Ages lived in the sphere of Islam. The Jewish population in Christian areas-meaning eastern and western Christendom-was quite small. Thus, the impact of Christian views on Jewish life was limited. Moreover, the small Jewish population in eastern Christendom and the southern sectors of western Christendom remained in the traditional areas of Jewish settlement, and thus Christian-Jewish relations showed little change from what they had been in late antiquity.

The second major external change in Jewish circumstances involved yet another alteration in the overall patterns of Western life. Beginning about mid-way in the Middle Ages-that is to say toward the end of the first millennium, western Christendom transformed itself from the weakest of the medieval religio-political power blocs into the strongest. By the year 1500, western Christendom had become the dominant force in the West, and its dominance would in fact grow over the course of the early modern and modern centuries. ${ }^{10}$ This new-found power in western Christendom was largely the result of the vitalization of the heretofore backward and unproductive areas of northern Europe-the areas that stretched from England in the west through northern France, Germany, and Poland in the east.

Down through the end of the first millennium, northern Europe was an under-populated and under-developed area of western Christendom. For reasons that are not at all clear, at the turn of the millennium northern Europe began to progress dramatically. Beginning slowly and unremarkably at the end of the first millennium, the backward areas of northern Europe began to develop in every respect: The population grew; arable land expanded; trade and industry devel-

9 For authoritative descriptions of the Islamic stance toward Judaism and Jews, see S. D. Goitein, Jews and Arabs: Their Contacts through the Ages (New York: Schocken, 1955), and B. Lewis, The Jews of Islam (Princeton: Princeton University Press, 2014).

10 For two outstanding analyses of this vitalization, see R. W. Southern, The Making of the Middle Ages (New Haven: Yale University Press, 1953), and J. Fried, The Middle Ages, trans. P. Lewis (Cambridge: Harvard University Press, 2015). 
oped; cities emerged out of villages; governance became increasingly effective; the institutions of religion and culture became better organized and more creative. A robust and relatively homogeneous civilization emerged across northern Europe, with its most powerful centers located in the western sectors of the north, with somewhat less mature centers in the middle sectors of the north, and with the eastern sectors lagging behind.

The vitalization of northern Europe had enormous impact on the history of the Jews, in ways not sufficiently acknowledged. As a result of this process, a sector of the world devoid of Jews quietly attracted a few early Jewish immigrants and then increasing numbers of Jewish settlers. Despite significant obstacles, this growing community of Jews took advantage of the remarkable developments occurring across northern Europe, contributed significantly to these developments, multiplied, and slowly emerged as the world's largest, most productive, and dominant Jewry. ${ }^{11}$ One of the results of the development of this new center of Jewish life was the emergence of new and baneful imagery of Judaism and Jews. In effect, the anti-Judaism of late antiquity evolved under these new circumstances into what emerged as a set of radically new negative stereotypes of Judaism and Jews that would become the foundations of modern antisemitism. ${ }^{12}$

The emergence and growth of northern-European Jewry was hardly an easy process. Northern Europe was a sector of the West in which the Jews were previously unknown. None of the familiarity that softened the growing size and centrality of the Jews of the Islamic sphere was in evidence across northern Europe. Instead, northern Europe was an area emerging fitfully from backwardness, an area dominated by the Roman Church, an area unaccustomed to religious diversity, an area undergoing rapid change with the resistance to change that often develops in such circumstances.

Jews came into this young society as a disruptive element. They were first and foremost newcomers, and newcomers are never enthusiastically welcomed into new societal settings. These newcomers were prized by the ruling authorities for the economic stimulation they might provide. However, this economic stimulation involved innovation and thus once again evoked resentment in many sectors of society that were resistant to change. Yet worse, these newcomers dissented from the Christian faith of the majority; indeed they were the descendants

11 In an overview of the history of the Jews in medieval Christian Europe, I have emphasized the differences between the older Jewry of southern Europe and the newer Jewry of northern Europe. See R. Chazan, The Jews of Medieval Western Christendom, 1000-1500 (Cambridge: Cambridge University Press, 2006).

12 See Chazan, From Anti-Judaism to Anti-Semitism. 
of those depicted in the Gospels as the enemies of Jesus. For all these reasons, the Jewish immigrants were widely viewed with disfavor-often intense disfavor-and regularly encountered resistance. That the Jewish population of northern Europe could continue to grow despite this resistance is a tribute to the vitality and attraction of this rapidly developing area and to the resourcefulness of its new Jewish population.

The initial resistance to the new Jewish settlers limited their economic diversification. Most of them came as traders, and few further options emerged for them. A curious development in the early twelfth century opened up a new and problematic economic opportunity for these Jews. As western Christendom and especially its northern sectors underwent rapid development, the increasingly powerful Roman Church began to agitate for observance of long-neglected prohibitions. One of these involved Christians taking usury from fellow Christians. ${ }^{13}$ Since flow of capital was critically important in rapidly developing northern Europe, the church's successes in this anti-usury initiative opened the way for Jewish specialization in moneylending. This new economic outlet was critical to maintaining the flow of capital across the north and to expanding Jewish presence in northern Europe. At the same time, it served to deepen popular animosity. While human societies recognize that banking and exchange of capital are critical to all economies, the people engaged in this activity are never popular. Jewish moneylending became yet another element in the increasingly negative imagery of northern Europe's Jews.

As we have seen, traditional Christian anti-Judaism projected the possibility of deleterious Jewish religious impact, and Augustinian policy insisted on limitation of this potential negative impact as one of the pillars of Christian policy vis-à-vis Jews. Moreover, the Gospel imagery of the Jewish opponents of Jesus deepened the perceptions of Jewish religious hostility to Christianity and Christians. In the new Jewish settlement area of northern Europe, perceptions of potential Jewish harmfulness were expanded far beyond the religious sphere. Potentially negative Jewish impacts on the Christian majority were perceived as extending into wide-ranging facets of societal life. To an extent, these perceptions were rooted in the realities of Jewish life. At the simplest level, Jews were agents of change. It is for this reason that they were supported by ruling authorities intent on fostering economic change and growth. Nonetheless, agents of change are never popular with certain strata of society, and so it was with the

13 The biblical source for this prohibition is Deuteronomy 23:20-21, which distinguishes between taking interest from a countryman, which is forbidden, and taking interest from a foreigner, which is permitted. 
new Jews of northern Europe. Moreover, the new Jewish specialization in moneylending-also supported by the authorities-exacerbated the sense of Jewish societal harmfulness.

Out of this expanded sense of potential Jewish harmfulness emerged a series of new, extreme, and highly damaging stereotypes of Jewish hatred of and malevolence toward Christianity and Christians. ${ }^{14}$ Jews traditionally perceived as religiously harmful and then in northern Europe as economically harmful, initially as a result of their involvement in economic change and subsequently as a result of their moneylending, were slowly perceived as deeply hostile and malevolent toward their Christian neighbors and moved to inflict devastating physical damage on these Christian neighbors whenever and wherever possible.

The initial form of this new perception was an alleged tendency on the part of Jews to murder groundlessly Christian contemporaries. Murder out of conflict of many kinds is lamentable but understandable and appears in all societies. However, the new sense that emerged in mid-twelfth-century northern Europe was that Jews killed Christian contemporaries without any specific grievance. Rather, it was simply hatred of all Christians that moved individual Jews to kill individual Christians. The groundlessness of these killings was emphasized by identifying the victims as children, who could not have done sufficient harm to their Jewish killers to warrant violence. A number of claims of groundless killing of Christian youngsters surfaced across northern Europe during the second half of the twelfth century. ${ }^{15}$

This sense of gratuitous Jewish murder was quickly embellished with religious motifs. The first such embellishment emerged in the English town of Norwich during the middle of the twelfth century. The Norwich chronicler Thomas of Monmouth claimed that eyewitness accounts of the murder of the saintly lad William indicated that the malevolent Jews took the youngster's life by crucifying him, in effect reenacting their historic crime. ${ }^{16}$ Thus the groundless murder of William was made yet more heinous by the form it took. Subsequently, the notion of murder in a ritualized format shifted from the allegation of Easter-related crucifixion to the Passover-related claim that Jews utilized the blood of

14 See especially the works of Langmuir and Chazan cited above in n. 2.

15 Chazan, Medieval Stereotypes and Modern Antisemitism, chap. 4.

16 See the classic study by G. I. Langmuir, “Thomas of Monmouth: Detector of Ritual Murder," Speculum 59 (1984): 822-46, reprinted in Langmuir, Toward a Definition of Antisemitism, 209-36. 
their Christian victims for Jewish holiday rituals. This powerful motif became a staple of anti-Jewish imagery down to the present. ${ }^{17}$

The notions of implacable Jewish hatred of Christians and the commitment of Jews to harming their Christian contemporaries took further forms, most notably the allegation of poisoning the wells of Europe in order to murder Christian neighbors. When in 1348-1349 Europe was devastated by the spread of the bubonic plague, Jews suffered the ravages of the plague along with everyone else. At the same time, in many places Jews were accused of creating the devastation by poisoning the water supply, and in some places these allegations resulted in popular massacres of Jews.

Traditional Christian anti-Judaism clearly played a role in these new medieval anti-Jewish calumnies, spawned initially in the areas of northern Europe where Jewish presence was new and resented. As we have seen, one of the sources of this resentment was Jewish deviation from the fundamentally Christian nature of the northern-European population. The notion of the murder of William of Norwich involving crucifixion and the later claim that Jews-via their moneylending-gained control of host wafers and subjected them to abuse all bespeak the impact of Christian thinking. ${ }^{18}$ At the same time, these new medieval calumnies clearly went far beyond traditional Christian anti-Judaism. Indeed, as these slanders emerged and spread, major church leaders regularly took a principled stance against them. For example, when the notion of Jewish ritual use of Christian blood emerged in the early thirteenth century, a series of popes denounced the claim and convened Christian experts in Jewish law to prove that the alleged Jewish behaviors were unthinkable. ${ }^{19}$ These new medieval allegations went far beyond traditional Christian anti-Judaism and in fact elicited church condemnation.

The new medieval slanders-grounded to an extent in traditional church thinking but extending far beyond that traditional thinking-were eventually absorbed into Western popular culture and played a significant role in the modern

17 See A. Dundes, ed., The Blood Libel Legend: A Casebook in Anti-Semitic Folklore (Madison: University of Wisconsin Press, 1991).

18 See M. Rubin, Gentile Tales: The Narrative Assault on Late Medieval Jews (New Haven: Yale University Press, 1999).

19 Note the reaction of Pope Innocent IV to the emergence of the blood libel accusation in the late 1240s-see S. Grayzel and K. R. Stow's two volumes on The Church and the Jews in the XIIIth Century (Philadelphia and New York: Dropsie College and Jewish Theological Seminary, 19331989), esp. 1:113-14, 262-67. Shortly thereafter, Pope Innocent IV added a new paragraph to the traditional Constitutio pro Judeis, prohibiting acceptance of the new allegation, see ibid., 1:118, 274-75. 
racist antisemitism that resulted in the murder of millions of Jews during the twentieth century. Traditional Christian anti-Judaism laid a foundation for modern antisemitism; this traditional Christian anti-Judaism was expanded in new and radical directions in the innovative circumstances of medieval Christian Europe. These new and radical directions constituted the more immediate backdrop to the extreme anti-Jewish imagery of modern antisemitism, which developed in much the same European areas that had spawned the more radical medieval anti-Jewish canards.

Robert Chazan has served as Scheuer Professor of Hebrew and Judaic Studies at New York University for the past three decades. The focus of Prof. Chazan's research has been the history of the Jews in medieval western Christendom. His most recent books are: From Anti-Judaism to Anti-Semitism (Cambridge University Press, 2016) and Refugees or Migrants: Pre-Modern Jewish Population Movement (Yale University Press, 2018).

\section{Bibliography}

Boyarin, Daniel. A Radical Jew: Paul and the Politics of Identity. Berkeley: University of California Press, 1994.

Carroll, James. Constantine's Sword: The Church and the Jews: A History. Boston: Houghton Mifflin, 2001.

Chazan, Robert. From Anti-Judaism to Anti-Semitism: Ancient and Medieval Christian Constructions of Jewish History. New York: Cambridge University Press, 2016.

Chazan, Robert. The Jews of Medieval Western Christendom, 1000-1500. Cambridge: Cambridge University Press, 2006.

Chazan, Robert. Medieval Stereotypes and Modern Antisemitism. Berkeley: University of California Press, 1997.

Chazan, Robert. Refugees or Migrants: Pre-Modern Jewish Population Movement. New Haven: Yale University Press, 2018.

Cohen, Jeremy. Living Letters of the Law: Ideas of the Jew in Medieval Christianity. Berkeley: University of California Press, 1999.

Crossan, John Dominic. The Historical Jesus: The Life of a Mediterranean Jewish Peasant. New York: HarperCollins, 1991.

Dundes, Alan, ed. The Blood Libel Legend: A Casebook in Anti-Semitic Folklore. Madison: University of Wisconsin Press, 1991.

Dunn, James D. G. The New Perspective on Paul. Grand Rapids: Eerdmans, 2008.

Fredriksen, Paula. Augustine and the Jews: A Christian Defense of Jews and Judaism. New York: Doubleday, 2008.

Fredriksen, Paula. From Jesus to Christ: The Origins of the New Testament Images of Jesus. New Haven: Yale University Press, 1988. 
Fried, Johannes. The Middle Ages. Translated by Peter Lewis. Cambridge: Harvard University Press, 2015.

Gager, John G. Reinventing Paul. Oxford: Oxford University Press, 2000.

Goitein, Shlomo Dov. Jews and Arabs: Their Contacts through the Ages. New York: Schocken, 1955.

Grayzel, Solomon. The Church and the Jews in the XIIIth Century: A Study of their Relations during the Years 1198-1254, based on the Papal Letters and the Conciliar Decrees of the Period. Philadelphia: The Dropsie College for Hebrew and Cognate Learning, 1933.

Grayzel, Solomon, and Kenneth R. Stowe. The Church and the Jews in the XIIIth Century 2: 1254-1314. New York: Jewish Theological Seminary, 1989.

Isaac, Jules. The Teaching of Contempt: Christian Roots of Anti-Semitism. Translated by Helen Weaver. New York: Holt, Rinehart \& Winston, 1964.

Langmuir, Gavin I. History, Religion, and Antisemitism. Berkeley: University of California Press, 1990.

Langmuir, Gavin I. "Thomas of Monmouth: Detector of Ritual Murder.” Speculum 59 (1984): $822-46$.

Langmuir, Gavin I. Toward a Definition of Antisemitism. Berkeley: University of California Press, 1990.

Lewis, Bernard. The Jews of Islam. Princeton: Princeton University Press, 2014.

Rubin, Miri. Gentile Tales: The Narrative Assault on Late Medieval Jews. New Haven: Yale University Press, 1999.

Sanders, E. P. The Historical Figure of Jesus. London: Penguin, 1993.

Sapir Abulafia, Anna. Christians and Jews in the Twelfth-Century Renaissance. London: Routledge, 1995.

Southern, Richard W. The Making of the Middle Ages. New Haven: Yale University Press, 1953.

Vermes, Geza. Jesus the Jew: A Historian's Reading of the Gospels. Philadelphia: Fortress, 1981.

Watson, Francis. Paul, Judaism, and the Gentiles: A Sociological Approach. Grand Rapids: Eerdmans, 2007. 
